\title{
STUDI KEBIASAAN MAKANAN IKAN BARONANG LINGKIS Siganus canaliculatus DI KEPULAUAN TANAKEKE TAKALAR SULAWESI SELATAN
}

\section{STUDI OF FOOD HABITS OF ‘ BARONANG LINGKIS’ FISH Siganus canaliculatus IN THE TANAKEKE ISLAND OF TAKALAR OF SOUTH SULAWESI}

\author{
Selviani, Irma Andriani dan Eddy Soekandarsi \\ Departemen Biologi, Fakultas Matematika dan IImu Pengetahuan alam \\ Universitas Hasanuddin, Makassar \\ Email : Selviani.ahmad@gmail.com
}

\begin{abstract}
Abstrak
Penelitian studi kebiasaan makanan Ikan Baronang Lingkis Siganus canaliculatus di Kepulauan Tanakeke Takalar Sulawesi Selatan telah dilakukan pada bulan Februari 2018. Penelitian ini bertujuan untuk mengetahui kebiasaan makanan ikan Baronang Lingkis berdasarkan habitat aslinya yaitu di Takalar Sulawesi Selatan. Jumlah sampel yang digunakan sebanyak 10 ekor. Sampel dibedah pada bagian belakang operculum dan menuju bagian dasar perut lalu sistem pencernaanya dipisahkan kemudian diawetkan dengan menggunakan formalin 1\%. Kemudian alat pencernaan dibedah lalu dikerik dan dikeluarkan semua isinya. Selanjutnya isi pencernaan diidentifikasi hingga tingkat spesies menggunakan referensi indentifikasi yang relevan. Hasil penelitian menunjukkan bahwa jenis-jenis makanan yang ditemukan adalah alga, lamun, crustacea dan detritus atau sisa makanan yang sulit teridentifikasi dan pasir. Hasil perhitungan nilai Indek preponderance (IP), diperoleh nilai tertinggi pada alga yaitu $58,3 \%$, lamun $20,5 \%$, detritus $20,5 \%$ dan crustacea $0,06 \%$. Penelitian ini menyimpulkan bahwa ikan baronang lingkis di kepulauan Tanakeke mempunyai kebiasaan memakan alga yang utama, lamun dan destritus sebagai tambahan dan crustacea makanan pelengkap.
\end{abstract}

Kata kunci : Tanakeke, Ikan Baronang, Kebiasaan Makanan.

\section{Abstract}

Research study of food habits 'Baronang Lingkis' fish Siganus canaliculatus in Tanakeke Island of Takalar of South Sulawesi was conducted in February 2018. This study aims to determine the food habits of 'Baronang Lingkis' fish on based of the original habitat of Takalar, South Sulawesi. The number of samples used is 10 tail. The sample was dissected at the back of the operculum and towards the bottom of the abdomen then the digestive system was separated and then preserved using $1 \%$ formalin. Then digestion tool dissected and then scraped and removed all the contents. Furthermore, the contents of the digestion are identified to the species level using the relevant identification reference. The results showed that the types of food found were algae, seagrass, crustaceans and detritus or unidentified food scraps and sand. The result of calculation of Preponderance Index (IP) value, obtained the highest value on algae that is $58,3 \%$, seagrass $20,5 \%$, detritus $20,5 \%$ and crustacea $0,06 \%$. This study concluded that the baronang fish in the Tanakeke island had a habit of eating the main algae, seagrass and destritus as a supplemental and complementary food crustacean.

Keywords: Tanakeke, Baronang Fish, Food Habits. 


\section{Pendahuluan}

Salah satu sumberdaya hayati perairan laut yang banyak dikonsumsi dan merupakan ikan favorit bagi pemancing di Indonesia adalah ikan Baronang (Siganus sp.). Ikan Baronang di Indonesia secara umum ada ikan Baronang susu (Siganuscanaliculatus), Baronang tompel (Siganus guttatus) dan Baronang angin (Siganus javus). Dari ketiga jenis itu yang paling sering dijumpai adalah Baronang susu (Siganuscanaliculatus). Kepulauan Tanakeke merupakan gugusan pulau-pulau kecil yang memiliki sumberdaya alam yang terbatas, namun memiliki sumberdaya kelautan yang melimpah. Kepulauan ini merupakan bagian dari wilayah Kabupaten Takalar di mana letaknya yang strategis untuk dikembangkan dengan basis kegiatan ekonomipada pemanfaatan sumberdaya alam dan jasa-jasa lingkungan (environmental services) (Rauf, 2008). Salah satu kelimpahan sumberdaya kelautan yang ada pada Kepulauan Tanakeke adalah ikan Baronang Lingkis Siganus canaliculatus. Kelimpahan populasi ikan tersebut salah satunya dipengaruhi oleh ketersediaan pakan dari ikan tersebut.

Jumlah populasi ikan dalam suatu perairan biasanya dipengaruhi beberapa faktor yang berhubungan dengan populasi tersebut, salah satunya yaitu ketersediaan, kualitas,serta mudah didapatnya pakan oleh ikan tersebut (Effendie 1997). Ketersediaan makanan adalah salah satu factor yang menentukan kelimpahan populasi, pertumbuhan, reproduksi, dan dinamika populasi serta kondisi ikan yang ada pada suatu perairan, Ikan yang mampu menyesuaikan diri ditinjau dari segi makanan adalah jenis ikan yang mampu memanfaatkan makanan yang tersedia dan bersifat generalis dalam memanfaatkan makanan alami, sehingga ikan tersebut mampu menyesuaikan diri terhadap fluktuasi kesediaan makanan alami (Tjahjo, 1998). Pengelolaan sumber daya ikan merupakan suatu aspek yang sangat menonjol disektor perikanan. Ketidakmampuan dalam pengelolaan sumber daya perikanan dapat berakibat pada kualitas sumber daya baik habitat maupun biota yang berasosiasi. Pengelolaan sumber daya ikan mempunyai cakupan yang luas dan terdiri atas berbagai aspek, salah satunya aspek biologi antara lain meliputi kebiasaan makanan dan reproduksinya (Muliati, dkk., 2017).

Secara umum kebiasaan makanan yang dimakan (food habit) oleh ikan dipengaruhi oleh kualitas dan kuantitas makanan yang dimakan, sehingga makanan kelimpahan ikan disuatau perairan, karena menentukan pertumbuhan dan kondisi ikan (Effendie, 1997). Kekurangan makanan akan membatasi jumlah populasi ikan disuatu perairan. Disamping itu tidak semua jenis makanan yang tersedia disukai oleh ikan. Jenis-jenis pakan alami yang dimakan ikan sangat bermacam-macam, bergantung pada jenis ikan dan tingkat umurnya. Benih ikan yang baru mencari makan, pakan utamanya adalah plankton nabati (fitoplankton) namun sejalan dengan bertambah besarnya ikan berubah pula makanannya begitu pula pada ikan baronang lingkis Siganus canaliculatus (Mudjiman, 1989). Salah satu faktor yang mempengaruhi jumlah populasi ikan ini adalah ketersediaan makanan di perairan tempat hidupnya. Makanan merupakan faktor yang penting dalam pertumbuhan ikan. Studi mengenai kebiasaan makanan ikan merupakan salah satu hal yang sangat penting dalam usaha pengelolaan dan budidaya ikan serta mampu memberikan pengetahuan mengenai interaksi atau hubungan makan-memakan yang terjadi dalam suatu komunitas. 


\section{Metode Penelitian}

Alat yang digunakan dalam penelitian ini adalah timbangan, penggaris, pisau bedah, pinset, mikroskop, cawan petri objek glass, cover glass, dan pipet. Bahan yang digunakan dalam penelitian ini adalah ikan Baronang jenis Siganus canaliculatus, formalin 1\%, tissue, dan aquades.

\section{Metode Kerja}

\section{a. Pengambilan Sampel}

Pengambilan ikan dilakukan dengan menggunakan jaring. Kemudian ikan dibelah pada bagian mulut sampai bagian anus secara horizontal sampai bagian belakang operculum dan menuju bagian dasar perut lalu sistem pencernaanya dipisahkan kemudian diawetkan dengan menggunakan formalin $1 \%$.

\section{b. Pengukuran Tubuh Sampel Ikan}

Panjang total tubuh ikan (TL) diukur menggunakan penggaris dalam satuan centimeter $(\mathrm{cm})$ dan berat tubuh ikan ditimbang dengan menggunakan timbangan digitall ketelitian 0,1 dalam satuan gram $(\mathrm{g})$.

\section{c. Prosedur Pemeriksaan Laboratorium}

Usus medaka yang telah diawetkan di dalam formalin $1 \%$ dibedah dengan menggunakan pisau bedah mulai dari anus menuju bagian atas perut. Lambung dipisahkan dari organ dalam lainnya. Saluran pencernaan setelah dibersihkan dari formalin kemudian dikerik, isi lambung dipisahkan. Isi lambung diencerkan dan diletakkan pada gelas objek dan diamati menggunakan mikroskop dengan perbesaran 10x4 dan 10x20 dengan menggunakan metode sensus sebanyak 3 kali ulangan. Metode sensus dilakukan dengan melihat frekuensi berapa kali jenis makanan tersebut muncul pada saat pengamatan di bawah mikroskop dengan melihat sebanyak 3 kali ulangan setiap usus dari masing-masing ikan. Kemudian isi alat pencernaan diidentifikasi menggunakan buku identifikasi yang relevan seperti buku Planktonologi.

\section{d. Analisis Data}

Analisis data yang digunakan pada penelitian ini adalah:

1. Indeks Bagian Terbesar (Index of Preponderance)

Penghitungan kebiasaan makanan secara kuantitatif digunakan Indeks Preponderance (Effendie, 1979). Indeks Preponderance adalah gabungan metode frekuensi kejadian volumetrik dengan rumus sebagai berikut :

$$
I P=\frac{V i x O i}{\sum(\text { VixOi })} X 100
$$

Keterangan : IP : Indeks preponderan(\%);

$\mathrm{Vi}$ : persentase volume satu macam makanan (\%)

Oi : persentase frekuensi keadaan satu macam makanan dan

$\Sigma($ VixOI) : Jumlah Vi x Oi dari semua macam makanan 
Mengacu pada Titrawani et al. (2013), presentase jumlah satu jenis makanan (Vi) dapat diketahui dengan menghitung jumlah satu jenis makanan dibagi dengan jumlah seluruh jenis makanan, dinyatakan dalam bentuk persen.

$$
\mathrm{V}=\frac{\text { jumlah individu satujenis }}{\text { jumlah seluruhjenis }} \times 100 \%
$$

Frekuensi kejadian makan (Oi) merupakan metode untuk mengetahui jumlah lambung yang berisi jenis makanan. Frekuensi kejadian makanan diketahui dengan cara menghitung jumlah lambung yang berisi satu jenis makanan dibagi dengan jumlah seluruh lambung yang berisi makanan dan dinyatakan dalam bentuk persen.

$$
\mathrm{Oi}=\frac{\text { jumlah lambung yang benisi satu jenis makanan }}{\text { jumlah seluruh lambung yang berisi makanan }} \times 100 \%
$$

Jika telah melakukan perhitungan indeks bagian terbesar (IP), maka bisa dianalisis dengan menggunakan indikator berikut:

IP $>40 \%$ sebagai makanan utama

IP $4-40 \%$ sebagai makanan tambahan

IP $<4 \% \quad$ sebagai makanan pelengkap.

\section{Hasil dan Pembahasan}

Pengambilan sampel dilaksanakan pada bulan Februari 2018 di Kepulauan Tanakeke Kabupaten Takalar. Sampel ikan yang ditangkap sebanyak 10 ekor dengan ukuran tubuh yang berbeda-beda namun perbedaannya tidak terlalu signifikan. Panjang ikan Baronang yang tertangkap, rerata 7-11 cm/ekor dengan berat rerata 8-20 gr/ekor. Setelah pembelahan usus ikan tersebut ditemukan yaitu Alga, lamun, krustacea dan detritus (Tabel 1).

Tabel 1. Jenis-jenis makanan yang ditemukan dalam usus ikan Baronang Lingkis Siganus canaliculatus

\begin{tabular}{|l|l|l|}
\hline No. & Kelompok Makanan & Jenis Makanan \\
\hline 1. & Alga & a. Oedogonium $s p$. \\
& & b. Zignema sp. \\
& & c. Garcillaria $s p$. \\
& & d. Hypnnea $s p$. \\
& & e. Nitzchia sp. \\
& & f. Chaetomorpha sp. \\
\hline 2. & Lamun & Tidak teridentifikasi \\
\hline 3. & Crustacea & Tidak teridentifikasi \\
\hline 4. & Detritus & Pasir dan sisa makanan yang hancur \\
\hline
\end{tabular}

Berdasarkan hasil pengamatan jenis makanan pada sistem pencernaan ikan baronang, ditemukan jenis alga yang dominan. Berarti ikan baronang lingkis Siganus canaliculatus merupakan hewan herbivore. Raharjo dkk., (2011), menyatakan bahwa ikan herbivora 
merupakan golongan ikan yang memakan bahan tumbuhan yang hidup di air atau di dalam lumpur, misalnya alga, hifa jamur, alga biru. Kebiasaan makan ini sesuai dengan morfologi gigi dan saluran pencernaan ikan baronang yaitu mulut yang berukuran kecil, usus halus panjang dan mempunyai permukaan yang luas.. Secara umum, organisme ikan dengan morfologi demikian, mempunyai makanan utama yakni lamun, sedangkan sebagai makanan pelengkapnya yaitu gastropoda, alga dan crustacea. Menurut Napitupulu (2013), ditemukan jenis tumbuhan pada lambung ikan baronang yang sebagian besar adalah potonganpotongan rumput laut. Hal ini diketahui karena masih terlihat potongan ataupun ada beberapa yang ditemukan kondisi utuh dan terlihat jelas berbentuk seperti jel dengan warna hijau kecokelatan serta serat tumbuhan lainnya. Faisal (2013), bahwa rumput laut merupakan salah satu makanan paling disukai ikan baronang, bahkan baronang merupakan hama bagi rumput laut'

Berdasarkan nilai Indeks Preponderance (IP) pada Tabel 2, dapat dilihat bahwa nilai IP tertinggi adalah alga yaitu $58,3 \%$; lamun $20,5 \%$; detritus $20,5 \%$ dan crustacea $0,06 \%$. Kondisi ini menunjukkan bahwa jenis makanan yang paling banyak ditemukan pada alat pencernaan ikan Baronang Lingkis Siganus canaliculatus yaitu Alga.

Tabel 2. Nilai Indeks Preponderance setiap kelompok makanan ikan Baronang Lingkis Siganus canaliculatus

\begin{tabular}{|c|c|c|c|c|c|c|}
\hline \multirow[t]{2}{*}{ No } & \multirow[t]{2}{*}{$\begin{array}{c}\text { Jenis } \\
\text { Organisme }\end{array}$} & \multicolumn{2}{|c|}{$\begin{array}{l}\text { Jumlah makanan } \\
\text { (Vi) }\end{array}$} & \multicolumn{2}{|c|}{$\begin{array}{c}\text { Frekuensi kejadian } \\
\text { (Oi) }\end{array}$} & \multirow[t]{2}{*}{$\begin{array}{c}\text { IP } \\
(\%)\end{array}$} \\
\hline & & jumlah & persentase & Jumlah & persentase & \\
\hline 1. & Alga & 85 & 58,2 & 10 & 100 & 58,3 \\
\hline 2. & Lamun & 30 & 20,5 & 10 & 100 & 20,5 \\
\hline 3. & Crustacea & 1 & 0,6 & 1 & 10 & 0,06 \\
\hline 4. & Detritus & 30 & 20,5 & 10 & 100 & 20,5 \\
\hline & Jumlah & & & & & 99,36 \\
\hline
\end{tabular}

Keterangan: IP : Indeks Preponderance

$\mathrm{Vi}$ : Persentase volume satu macam makanan

Oi : Persentase frekuensi keadaan satu macam makanan

INDEKS PREPONDERANCE (\%)

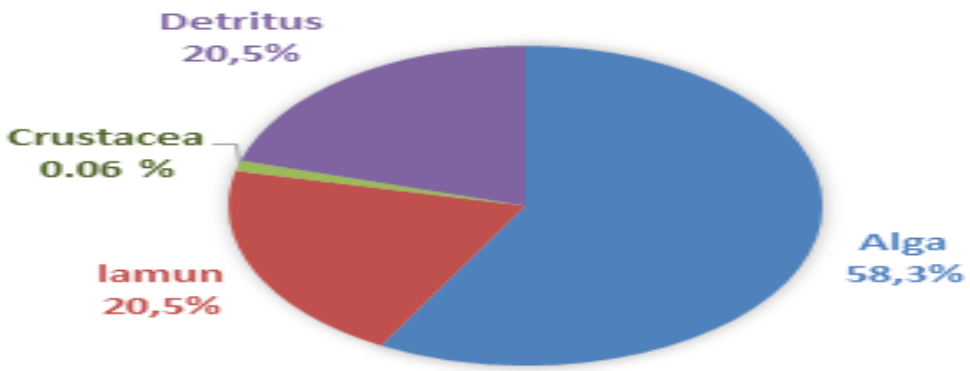

Gambar 1. Diagram lingkaran komposisi nilai Indeks Propenderance (IP) (\%) Ikan Baronang Lingkis Siganus canaliculatus 
Jenis alga yang banyak ditemukan pada saat proses pengamatan adalah alga dengan ciri-ciri memiliki bentuk thallus menyerupai rambut-rambut halus atau bulu-bulu. Menurut Christensen dkk., (1990), alga dengan ciri tersebut merupakan jenis Chaetomorpha sp. Sedangkan beberapa jenis alga yang ditemukan dalam jumlah yang sedikit yaitu Zygnema sp, Oedogonium sp dan Nitzchia sp. Pauly dkk., (1990), menyatakan bahwa komposisi makanan utama ikan famili siganidae adalah daun lamun. Preferensi makanan yang paling banyak dimakan oleh ikan baronang dewasa maupun juvenil adalah lamun. Pernyataan ini juga mendukung hasil penelitian, bahwa pada ketiga ekosistem laut yakni mangrove, terumbu karang dan lamun, makanan yang lebih dominan di makan oleh ikan baronang adalah lamun. Ambo-Rappe dkk., (2011), menemukan isi perut ikan baronang didominasi oleh potongan lamun Enhalus acoroides dan Halophila ovalis. Kemudian Merta (2005) dalam Ambo-rappe dkk (2011) pada ikan baronang Siganus canaliculatus dari perairan Teluk Banten, ditemukan bahwa ikan tersebut pemakan lamun jenis Enhalus acoroides, Tahalassia hemprichii, Halophila ovalis, Cymodocea rotundata, Haludole uninervis dan Syringodium isoetifolium. Kordi (2009) dalam Ambo-rappe dkk (2011) juga membuktikan bahwa ikan baronang memakan lamun, alga ataupun lumut. Ikan ini juga pada fase larva memakan plankton dan menjadi herbivore pada saat sudah aktif mencari makan.

Pada penelitian ini juga ditemukan satu jenis debris crustacea atau salah satu bagian potongan anggota tubuh crustacea pada salah satu sampel. Kebiasaan makan crustacea cenderung sedikit dibandingkan dengan lamun dan alga. Menurut Nurnaningsih dkk.,2005 dalam Muliati, dkk., (2017), bahwa perubahan makanan ikan selain dipengaruhi faktor selera ikan dengan ketersediaan makanan juga dipengaruhi oleh lebar bukaan mulut. Sedangkan Jenning, (2003), bahwa kebiasaan makan suatu spesies ikan juga tergantung model dan ukuran mulut. Kebiasaan makanan dan cara memakan ikan secara alami juga tidak terlepas pada lingkungan tempat hidup ikan. Mayunar (2002), bahwa ikan Baronang mampu memakan apa saja yang diberikan seperti pakan buatan.

Berdasarkan hasil perhitungan nilai Indeks Preponderance (IP), alga dinyatakan merupakan makanan utama ikan baronan lingkis pada lokasi Tanakeke karena nilai Ipnya $58,3 \%$. Apalagi kondisi laut Tanakeke merupakan penghasil rumput laut. Sedangkan lamun dan destritus yang memiliki nilai indek preponderance sama yaitu 20,5\% dinyatakan sebagai makanan tambahan. Crustacea memiliki nilai Indeks Preponderance (IP) paling sedikit yaitu 0,06\% yang berarti Crustacea ini masuk sebagai makanan pelengkap. Menurut Effendii (1979), nilai IP > 40\% merupakan makanan utaman, IP 4-40\% makanan tambahan dan $<4 \%$ makanan pelengkap

\section{Kesimpulan}

Penelitian ini menyimpulkan bahwa pada sistem pencernaan ikan Baronang Lingkis Siganus canaliculatus ditemukan jenis makanan berupa alga, lamun, crustacea dan detritus. Alga merupakan makanan utamanya karena nilai indek preponderance 58,3\% dibandingkan lamun $20,5 \%$, destritus $20,5 \%$ dan crustacea $0,06 \%$. 


\section{Daftar Pustaka}

Ambo-Rappe, Rohani, Budimawan, Fahyra Agustina, 2011. Preferensi dan Daya Ramban Ikan Baronang, Siganus canaliculatus Pada Berbagai Jenis Lamun. Jurnal. Jurusan IImu Kelautan, Fakultas IImu Kelautan dan Perikana, Universitas Hasanuddin. Makassar.

Christensen, P. B., L. P. Nielsen, N. P. Revsbech and J. Sorensen. 1990. Denitrification in nitrate-rich streams. Diurnal and seasonal variation related to benthic oxygen metabolism. Limnology and Oceanography 35:640-651.

Effendie, M. I. 1979. Metode Biologi Perikanan. Yayasan Dewi Sri.Yogyakarta.

Effendie, M.I. 1997. Biologi Perikanan.Yayasan Pustaka Nusantara. Yogyakarta.

Faisal, L., O., 2013. Pertumbuhan Rumput Laut (Kappaphycus alvarezii) dan Ikan Baronang (Siganus guttatus) yang dibudidayakan Bersama di Keramba Tancap. Jurnal Mina Laut Indonesia, 1(1)

Jenning, 2003. Marine Fisheries Ecology. Centre For Enviroent, Fisheries and Agriculture Science. Hong Kong.

Mayunar, dan A., Genisha, 2002. Budidaya Ikan Kakap Putih. Jakarta.

Mudjiman, A. 1989. Makanan Ikan. Penebar Swadaya. Jakarta.

Muliati, Yasidi, Farid, dan Arami, Hasnia, 2017. Studi Kebiasaan makanan Ikan Baronang (Siganus canaliculatus) di Perairan Tondonggeu Kecamatan Abeli Sulawesi Tenggara. Jurusan Manajemen Sumberdaya Perairan, Fakultas Perikanan dan IImu Kelautan, Universitas Haluoleo. Kendari.

Napitupulu, M., dan Mujiyanto, 2013. Analisa Kebiasaan Makan Ikan Baronang (Siganus virgatus) di Kepulauan Kerimunjawa, Jawa Tengah. Prosiding Seminar Nasional Tahunan X Hasil Penelitian Kelautan dan Perikanan. Jurusan Perikanan Fakultas Pertanian UGM, Yogyakarta.

Pauly VJ, Nelson SG, Sanger H., R., 1990. Feeding Preferences Of Adult And Juvenile Rabitfish Sianus Argenteusin Relation To Chemical Defence Of Tropical Seaweeds. Journal Of Marine Ecology Progress Series. 60:23-34.

Rauf, Abdul, 2008. Pengembangan Terpadu Pemanfaatan Ruang Kepulauan Tanakeke Berbasis Daya Dukung. Disertasi, Sekolah Pascasarjana, Institut Pertanian Bogor. Bogor.

Titrawani, R., Elvyra, dan R., U., Sawalia, 2013. Analisis Lambung Ikan Senangin (Eleutheromena tertractylum Shaw) di Perairan Dumai. Al-Kauniyah Jurnal Biologi.: 
6 (20): 85-90.

Tjahjo, D. W. H. dan Kunto Purnomo.1998. Studi Interaksi Pemanfaatan Pakan Alami Antar Ikan Sepat (Trichogaster pectoralis), Betok (Anabastestudineus), Mujair (Oreochromis mossambicus), Nila (O. niloticus) dan Gabus (Channa striatus) di Rawa Taliwang. Bull. Penel.Perik. Indonesia, IV (3) : 50 - 59. 